\title{
Presence of organochlorine pesticides in xoconostle (Opuntia joconostle) in the central region of Mexico
}

\author{
José J. Pérez , Rutilio Ortiz*, María L. Ramírez ${ }^{1}$, Javier Olivares², Daniel Ruíz ${ }^{2}$ and David Montiel ${ }^{2}$
}

\begin{abstract}
Background: Mexico has many natural resources for use in the food industry. In recent years Xoconostle, which is considered as a traditional food, has gained importance due to key its components such as fiber, antioxidants, and fermentative bacteria found in both the peel and fruit, which could benefit human and animal health. Information on the presence of organic contaminants such as pesticides in Xoconostle is important in protecting its reputation as a healthy food. The objective of this research was to measure the concentration of pesticides in the peel of Xoconostle in four $50 \mathrm{~m}^{2}$ plots in the same production area. The samples were taken in the state of Hidalgo, which is one major region of production. Fruits were collected from upper and lower levels in five plots. Organochlorine pesticides in peel samples were extracted by Soxhlet extraction, purified with chromatographic columns, and finally analyzed by gas chromatography with electron capture detector (ECD).

Results: The results showed a predominance of heptachlor, $\mathrm{HCH}$ derivatives and DDT isomers but there is no permissible limit for these compounds in this fruit.

Conclusions: The presence of organochlorines suggests the use of these compounds in control of pests in crops and livestock, in spite of the substitution of these compounds, principally by organophosphorus pesticides. Regulation is necessary to ensure the safety of the product for consumption and trade.
\end{abstract}

Keywords: Traditional food, Organochlorine compounds, Contamination

\section{Background}

Mexico has 93 species of cactus, some of which are commercially important for food and health uses. Opuntia joconostle (known as Xoconostle) is one such example. In recent years, Xoconostle uses have been growing due to its health benefits, as well as other applications such as a condiment in Mexican cuisine, and in the preparation of candies, jellies and beverages. The Xoconostle may remain in the processing plant for several months without deteriorating, and it can be kept for several weeks in a dry and cool environment without losing its flavor or moisture (Osorio-Esquivel et al. 2011). Xoconostle has been used as a so-called natural treatment for diabetes, hypertension, obesity, and respiratory ailments. There is

\footnotetext{
* Correspondence: guppyabanico@gmail.com

'Departamento de Producción Agrícola y Animal, Laboratorio de Análisis Instrumental, Universidad Autónoma Metropolitana, Unidad Xochimilco, Calzada del Hueso No 1100, Colonia Villa Quietud, Delegación Coyoacán C.P. 04960, D.F., México

Full list of author information is available at the end of the article
}

evidence that its consumption causes a reduction in cholesterol levels, a gradual decrease of seric glucose levels, and an increase in seric insulin levels (Morales et al. 2012, Osorio-Esquivel et al. 2011). This fruit has been consumed since pre-Hispanic times, especially in semiarid regions in the central area of Mexico (Saenz et al. 2006; Morales et al. 2012).

Cactus fruits have attracted the attention of national and international researchers due to their commercial value. For example, in some regions the cactus has been employed as an ornamental plant due to its colorful flowers, and as an agricultural crop due to its fruits and the ability of its roots to help improve soil structure and to work in association with nitrogen fixing bacteria/mycorrhiza to help absorption of phosphorous (Saenz et al. 2006). The cactus has a high adaptability to extreme conditions of drought, cold, and thin soils poor in nutriments (Guzmán et al. 2010). Xoconostle peel is useful as food for livestock and alcoholic beverages by fermentation, and in the central region of 
Mexico it is considered a good option to provide income for the population, and food for animals (Guzmán et al. 2010). It has been exported to others countries for similar uses in conservation of soil and as an alternative source of nutrition for livestock and human populations (Morales et al. 2012).

The increasing use of the Xoconostle suggests the need to investigate the possibility of contamination of the crop (Saenz et al., 2006). Farmers apply pesticides such as organochlorine and organophosphorous compounds to control pests. Some are prohibited while others including some organochlorine compounds (mainly heptachlor and DDT) may still be used in some countries. Pesticides have played a key role in providing reliable supplies of agricultural produce at prices affordable to consumers, and ensuring high profits to farmers (Wang 2013). Many investigations have shown the occurrence of organochlorine compounds in soil, water, forage, foods (animal and vegetable) in production systems. Levels of contamination are often found to be broadly related to anthropogenic activities (contamination sources) such as cities, commercial plantations/livestock, tourism and health campaigns to malaria (Narayan et al. 2012).

Contamination by pesticides is influenced by physicchemical characteristics and environmental variables (temperature, oxygen, water, light, microorganisms, organic matter and others). Inevitably pesticides are present in the environment and can be found in agricultural products, food for livestock, wood and derivatives. Despite their popularity and excessive use, exposure of the general population to pesticides originating from pesticide residues in food, air and drinking water generally involves low doses and is chronic (or semi-chronic) in terms of health effects (Wang et al. 2013).

The presence of pesticides in agriculture is common in food for animal or human consumption; it is of course a topic of interest which concerns the quality of produce and the health of consumers and is of particular importance for regional agricultural products. The aim of this study was to determine the concentration of organochlorine pesticides on the EPA priority list in the peel of Xoconostle.

\section{Methods}

\section{Sampling}

Xoconostle fruits were sampled in five $50 \mathrm{~m}^{2}$ plots from the state of Hidalgo, Mexico. We collected fruits in January from the upper, medium and lower levels of the plants in a zigzag sampling pattern to obtain a composite sample of $3 \mathrm{~kg}$ from each production unit according at NOM-007-RECNAT-1997; ripe fruits were picked fresh from the plant. The samples were transported to the laboratory at $4{ }^{\circ} \mathrm{C}$ and stored at this temperature until their analysis.

Of the pests that affect both the prickly pear plant and the fruit, the most important are: weevil borer (Cactophagus spinolae) with high densities in May to August; weevil thorns (Cylindrocopturus birraddiatus), with high populations in April and May; white worm, zebra, cochineal (Dactylopius indicus), which occurs all year round; bedbug gray (Chelinidae tabulatus), which is present all year with older populations from September to December; red bedbug (Hesperolabops gelatops), increased populations from August to November; prickly pear thrips (Sericothrips opuntiae) with high populations from February to April. Needless to say, the presence, incidence and severity of damage vary from region to region, and is also dependent on cultural practices and pest management. The application of pesticides to crops began using chlorinated compounds in the 1960s and these have largely been replaced by organophosphate compounds in recent decades.

\section{Extraction of organochlorine pesticides}

The peel was selected for analysis because of its lipid composition and its common use for animal consumption and in the fermentation process for alcoholic beverages. Prior to extraction the peel was removed with a knife cleaned with HPLC grade solvent to avoid cross contamination. The peel was dried at $40{ }^{\circ} \mathrm{C}$ in a drying oven for four days and reported results are presented as mass per mass of dry matter. The organochlorine compounds in peel of Xoconostle were extracted by Soxhlet extraction (hexane/dichloromethane 1:1 v/v) according 3540C EPA (1996), and purified with chromatographic columns (desactived Florisil, method 3620C EPA 2014). The eluent from the columns was concentrated by rotatory evaporation to $3 \mathrm{~mL}$ and then transferred to a small vial for gas chromatography analysis according to USEPA methodology (Method 8081B) (EPA 2007).

\section{Chromatographic analysis}

The samples were analyzed by gas chromatography with electron capture detection (GC-ECD, HP 6890 Series, Wilmington; DE, USA). (Column HP-5, $30 \mathrm{~m}, 0.25 \mathrm{~mm}$ ID, $0.25 \mu \mathrm{m}$ film thickness, crosslinked 5\% PH ME Siloxone, Waltham, MA, USA). The oven temperature was initially set at $90{ }^{\circ} \mathrm{C}$ and held for $2 \mathrm{~min}$, then ramped at $30{ }^{\circ} \mathrm{C} \mathrm{min}{ }^{-1}$ to $180{ }^{\circ} \mathrm{C}(0 \mathrm{~min})$, then ramped at $1{ }^{\circ} \mathrm{C} \mathrm{min}{ }^{-1}$ to $200{ }^{\circ} \mathrm{C}(0 \mathrm{~min})$, and ramped at $10{ }^{\circ} \mathrm{C} \mathrm{min}^{-1}$ to a final temperature of $300{ }^{\circ} \mathrm{C}$ (6 min), with a total analysis time of $41 \mathrm{~min}$. Detector and injector temperatures were $320{ }^{\circ} \mathrm{C}$. The carrier gas was high purity helium (99.99\%) with flow of $6 \mathrm{~mL} / \mathrm{min}$ and make up of nitrogen gas with a flow of $60 \mathrm{~mL} / \mathrm{min}$. A sample of $1 \mathrm{~mL}$ was injected in splitless mode.

The organochlorine pesticides analyzed were 16 compounds identified according to an EPA priority list. They were: 1) alpha, 2) beta, 3) gamma (Lindane) and 4) delta $\mathrm{HCH}$; 5) heptachlor; 6) aldrin; 7) heptachlor epoxide; 8) endosulfan I; 9) p,p'-DDE; 10) dieldrin; 11) 
endrin; 12) endosulfan II; 13) p,p'-DDD; 14) endrin aldehyde; 15) endosulfan sulfate and 16) p,p'-DDE (PPO-8JM, Chem Service Inc, West Chester, PA, USA). An external method for quantification of organochlorine compounds based on retention times was used.

\section{Quality control}

The analysis included solvent blanks, spiked recoveries, replicate analysis and comparison of standards. Solvent blanks were run with each sample batch. All solvents and others materials contacting samples were not contaminated with the analytes, as confirmed by analysis of solvent blank samples. Spiked recovery tests were performed periodically during analyses. All of these showed acceptable recoveries between 80 and $95 \%$ and limits of detection were between 0.10 and $0.30 \mathrm{ng} / \mathrm{g}$ (Table 1).

Comparison of chromatograms of fortified and unfortified blanks provided further confidence of the quality of the method. The specificity of the method was checked daily through comparison of chromatograms at the retention times of the analyses. The middle standard of the calibration curve was injected daily to evaluate the performance of the GC. Where necessary, blank subtraction was used for areas of the chromatogram where interference occurred in samples with values were close to limits of detection. The areas of the samples were corrected by subtraction of the appropriate contaminant area, adjusted for recovery values.

Table 1 Values of limit of detection for Xoconostle analysis

\begin{tabular}{|c|c|c|c|c|}
\hline Pesticides & $\begin{array}{l}\text { Retention } \\
\text { times } \\
\text { (min) }\end{array}$ & $\begin{array}{l}\text { Limit of } \\
\text { detection } \\
(\mathrm{ng} / \mathrm{g})\end{array}$ & $\begin{array}{l}\text { Recovery } \\
(\%)\end{array}$ & $\begin{array}{l}\text { Standard } \\
\text { deviation } \\
(+/-)\end{array}$ \\
\hline Alpha-HCH & 9.83 & 0.10 & 90 & 7 \\
\hline Beta-HCH & 10.64 & 0.10 & 88 & 5 \\
\hline Gamma-HCH & 10.87 & 0.16 & 85 & 8 \\
\hline Delta-HCH & 11.74 & 0.21 & 80 & 6 \\
\hline Heptachlor & 13.92 & 0.30 & 90 & 9 \\
\hline Aldrin & 15.81 & 0.30 & 88 & 4 \\
\hline Heptachlor epoxide & 18.42 & 0.22 & 89 & 10 \\
\hline Endosulfan I & 21.14 & 0.20 & 85 & 2 \\
\hline DDE & 23.39 & 0.18 & 95 & 8 \\
\hline Dieldrin & 23.65 & 0.15 & 92 & 7 \\
\hline Endrin & 25.31 & 0.10 & 90 & 9 \\
\hline Endosulfan II & 26.12 & 0.12 & 85 & 5 \\
\hline DDD & 27.11 & 0.18 & 90 & 6 \\
\hline Endrin aldehyde & 27.42 & 0.13 & 82 & 5 \\
\hline Endosulfate sulfate & 28.73 & 0.20 & 95 & 2 \\
\hline DDT & 29.05 & 0.30 & 85 & 9 \\
\hline
\end{tabular}

Note: $\mathrm{HCH}=$ Hexachlorociclohexane, $\mathrm{DDE}=1,1$-dichloro-2,2-bis (4 chlorophenyl) ethylene, DDT = 1,1,1-trichloro-2,2-bis (4 chlorophenyl) etano, DDD = dichlorodiphenyldichloroetane
The method detection limits (DLs) were defined by the injection of standard solutions whose signal-to-noise $(\mathrm{S} / \mathrm{N})$ ratios were at least three; values ranged from 0.1 to $0.3 \mathrm{ng} / \mathrm{g}$. Those samples with concentrations detected less than DLs were treated as not detected (n.d.).

\section{Results and discussion}

Table 2 shows the concentrations of the organochlorine compounds in the plots. Plots 1, 4 and 5 generally showed a greater abundance of pesticides. Heptachlor, endosulfan, p,p'-DDE, endrin, beta and gamma $\mathrm{HCH}$ were dominant in plot 1 ; p,p'-DDE, heptachlor, endrin aldehyde, gamma $\mathrm{HCH}$ (lindane), endrin, heptachlor epoxide and aldrin in plot 4, and aldrin, heptachlor, gamma, delta and beta $\mathrm{HCH}$ in plot 5. The order of total concentration of the organochlorine pesticides was Plot 4 Plot $1>$ Plot5 $>$ Plot $3>$ Plot2. There was no significance difference among plots $(p=0.05)$. The plots were located in one municipality of Hidalgo.

In general, heptachlor was present at the greatest concentrations in most of the plots followed by aldrin, epoxide and p,p'-DDE. The isomers of $\mathrm{HCH}$ were present in all of the plots. Heptachlor is used to control pests such as Sericotrips opuntiae Hood, Melanotus sp and Phyllophaga spp that are common in Xococnostle plantations. Endosulfan use is permitted in Mexico to control Cactophagus spinolae Gyll, and lindane has restricted use status to help control Cylindrocopturus birradiatus Champ and Chelinidea tabulata Burn (INE, 2003). The presence of organochlorine compounds in the plantations is indicative of use to control pests in vegetables and livestock. The use of aldrin in Mexico is forbidden because of its high risk to human health, although it is thought that some illegal use occurs due to its low cost.

The presence of isomers of DDT as p,p'-DDE and p,p'DDD are indicative of use in the past to control pests. DDT is now prohibited for this use and has been replaced by technical lindane that contains contaminants. This could be seen by the presence of isomers of $\mathrm{HCH}$ in the plots. Xoconostle peel acts as natural barrier due to its lipidic composition in the form of waxes; pesticides deposited on the fruit peel remain there due to their lipophilic characteristics (Gutiérrez et al. 2010). It was assumed that all contaminants remained in the peel.

Gutiérrez et al. (2010) determined the organochlorine pesticides in peel and fruit of pineapple. They found heptachlor $(7.13 \mathrm{ng} / \mathrm{g})$, aldrin $(9.9 \mathrm{ng} / \mathrm{g})$, DDE $(4.6 \mathrm{ng} / \mathrm{g})$ and heptaclor epoxide $(12.4 \mathrm{ng} / \mathrm{g})$, mostly in the peel. Low levels of these compounds were found in peel of Xoconostle in this study, in terms as average concentration of the same compound for the plots studied in the study area. For example, concentrations were heptachlor (0.34 ng/g), aldrin (0.25 ng/g), DDE (0.18 ng/g) and heptachlor epoxide $(0.12 \mathrm{ng} / \mathrm{g})$. 
Table 2 Concentrations of organochlorine pesticides in plots from Hidalgo, Mexico

\begin{tabular}{|c|c|c|c|c|c|}
\hline \multirow[t]{2}{*}{ Compounds } & \multicolumn{5}{|l|}{ Plots (ng/g) } \\
\hline & 1 & 2 & 3 & 4 & 5 \\
\hline Alpha $\mathrm{HCH}$ & $0.10 \pm 0.02^{*}$ & LD & LD & LD & $0.10 \pm 0.06$ \\
\hline Beta $\mathrm{HCH}$ & $0.18 \pm 0.08$ & LD & LD & LD & $0.20 \pm 0.09$ \\
\hline Gamma HCH & $0.18 \pm 0.07$ & LD & $0.18 \pm 0.09$ & LD & $0.23 \pm 0.14$ \\
\hline Delta $\mathrm{HCH}$ & LD & LD & LD & $0.27 \pm 0.12$ & $0.21 \pm 0.09$ \\
\hline Heptachlor & $0.60 \pm 0.09$ & LD & LD & $0.45 \pm 0.15$ & $0.50 \pm 0.28$ \\
\hline Aldrin & $0.43 \pm 0.10$ & LD & LD & LD & $0.55 \pm 0.19$ \\
\hline Epoxide of heptachlor & $0.37 \pm 0.11$ & LD & LD & $0.22 \pm 0.06$ & LD \\
\hline Endosulfan I & $0.20 \pm 0.05$ & LD & LD & LD & LD \\
\hline $\mathrm{p}, \mathrm{p}^{\prime}-\mathrm{DDE}$ & $0.19 \pm 0.05$ & LD & LD & $0.72 \pm 0.35$ & LD \\
\hline Dieldrin & LD & LD & LD & $0.18 \pm 0.08$ & LD \\
\hline Endrin & $0.16 \pm 0.09$ & LD & LD & $0.25 \pm 0.11$ & LD \\
\hline Endosulfan II & LD & LD & LD & $0.13 \pm 0.07$ & LD \\
\hline$p, p^{\prime}-D D D$ & LD & LD & LD & $0.18 \pm 0.08$ & LD \\
\hline Endrin aldehyde & LD & LD & LD & $0.43 \pm 0.25$ & LD \\
\hline Endosulfan sulfate & LD & LD & LD & LD & LD \\
\hline $\mathrm{p}, \mathrm{p}^{\prime}-\mathrm{DDT}$ & LD & LD & LD & $0.30 \pm 0.06$ & LD \\
\hline Total & $2.41 \pm 0.66$ & LD & $0.18 \pm 0.09$ & $3.13 \pm 1.33$ & $1.79 \pm 0.85$ \\
\hline
\end{tabular}

Note: LD below of limit of detection, ${ }^{*}$ Standard deviation $\sigma$

Fenik et al. (2011) analyzed the presence of organochlorine pesticides and their risks in vegetables; their results showed not authorized or restricted pesticides according to the National Reference Center for Pesticides and Contaminants in 2005 and 2007 in several vegetables including the stem cactus. For example, the presence of endosulfan in cilantro and guava was indicative of the continued use of organochlorine compounds by farmers. They also found organophosphate pesticides that were not authorized for use on the crops examined. Considering Mexico, Pérez et al. (2013) showed that even though several harmful pesticides have been banned, while some are authorized for use despite being prohibited in many countries. There are reports of a number of obsolete products in use or being stored inappropriately that pose risks to the environment further of inadequate regulation and management, trade, weak enforcement of bans on pesticides importation, illegal use/application and lack of logistics to monitor these pesticides (Okoffo et al., 2016). The presence of pesticide residues in vegetables and fruits is frequent, being reported in over $50 \%$ of the samples tested in national monitoring and in products exported to the United States in specific studies.

The Codex Alimentarius does not state any residual permissible limit for organochlorine pesticides in Xoconostle, however there are values for a few vegetables (Table 3) that can be used for comparison. It is important that national and international institutions responsible for control of contaminants in food consider the presence of organochlorine pesticides in Xoconostle, and the use in alternative diets. In addition, other chlorine compounds such as lindane do not have a permissible limit in vegetables.

Pesticide residues in fruits and vegetables are a major concern to consumers due to their negative impacts on health. They have been found in both raw and processed fresh produce. However, food processing techniques have been found to significantly reduce the pesticide residues in fruits and vegetables (Chen et al. 2011). The main processes that reduced pesticide residue levels were blanching, cooking, frying, peeling and washing. Washing has been found to reduce pesticides that are loosely attached to the surface while peeling removes even those that have penetrated the cuticles of the fruits or vegetables (Latif et al., 2011). Food safety is an important consideration because of domestic/international trade and the potential health implications for the consumer.

Table 3 Residual permissible limit for some plantations

\begin{tabular}{lll}
\hline Pesticide & Food & $\begin{array}{l}\text { Residual } \\
(\mathrm{mg} / \mathrm{kg})\end{array}$ \\
\hline Heptachlor & Pineapple & 0.01 \\
Aldrin & Leaf vegetables & 0.05 \\
DDT & Carrot & 0.2 \\
Endrin & Cucurbits and vegetables & 0.05
\end{tabular}

Codex Alimentarius, 2015 
In addition, many investigations refer to the study of fruits and vegetables with high consumption such as lettuce, radishes, carrots, squash, spinach, apple, orange, pineapple, which are among those that are most traded worldwide (Fenik et al., 2011; Narayan et al. 2012). The recent commercialization and promotion of consumption of other fruits and vegetables (named traditional or regional) by international organizations such as the FAO, thought of as giving benefits to health either through fresh consumption or after processing, has generated the need for regulations to national and international standards to ensure safety (FAO, 2015).

Figure 1 shows the total distribution of organochlorine pesticides in the Xoconostle peel, where heptachlor was present at a relatively high concentration in the plantation, followed mainly by, aldrin, epoxide of heptachlor, p,p'-DDE, dieldrin and endrin. These compounds are typical of control of pests in zones related to agricultural and livestock activities.

The distribution of pesticides in the current study indicate the use of $\mathrm{HCH}$ for control of pests but the product is probably a technical grade due to the presence of contaminants such as alpha and beta isomers (Fenik et al., 2011, Pérez et al. 2013). This compound is employed extensively in rural zones dedicated to agriculture, employed in human health (gamma $\mathrm{HCH} /$ lindane to control lice on children), and in livestock activities. According to INE (2003), there several denominations for this pesticide employed for sale among farmers in an attempt to use old stock. Many studies concerning the toxicology of organochlorine compounds in Mexico have focused on cow's milk, breast milk, fat tissue, sediments and mollusks. Despite the intention to replace their use by organophosphorus compounds, they are still used frequently as a cheap alternative in developing countries by food producers. Mexico is a signatory of an international treaty that only allows the use of DDT in special cases for health reasons (control of malaria vectors). The concentration of DDE surpasses that of DDT in Xoconostle plantations, an indication that degradation of residues already present is occurring, not of continued use. The presence of other organochlorine compounds such as endrin, endosulfan, aldrin and dieldrin is also likely to be due to their residual presence as their use is forbidden or restricted in agriculture (Fenik et al., 2011; Narayan et al. 2012)

Organochlorine pesticides can be classified according to their chemical structure as alicyclic, cyclodienics and, aromatic. The family groups that were measured in the plots from the municipality were: Plot 1, alicyclics $0.46 \mathrm{ng} / \mathrm{g}$, cyclodienics $1.76 \mathrm{ng} / \mathrm{g}$ and aromatics $0.19 \mathrm{ng} / \mathrm{g}$; Plot 2 no detectable organochlorine compounds present; Plot 3 only alicyclics $0.18 \mathrm{ng} / \mathrm{g}$; Plot 4 alicyclics $0.27 \mathrm{ng} / \mathrm{g}$, cyclodienics $1.66 \mathrm{ng} / \mathrm{g}$ and aromatics $1.20 \mathrm{ng} / \mathrm{g}$, and finally plot 5 alicyclics $0.74 \mathrm{ng} / \mathrm{g}$ and cyclodienics $1.05 \mathrm{ng} / \mathrm{g}$. The cyclodienics were present at the greatest concentrations followed by alicyclics and aromatics.

The cyclodienics include heptachlor, aldrin, epoxide of heptachlor, endosulfan, dieldrin, endrin, endrin aldehyde and endosulfan sulfate. Heptachlor, within its group, had a relatively high concentration, probably because it is used in cactus plantations mainly for the control of pests. The alicyclics include isomers of $\mathrm{HCH}$, used widely to control agricultural and livestock pests. The aromatics include DDT, DDE and DDD, which as previously mentioned, have been forbidden since 1980 in Mexico by international

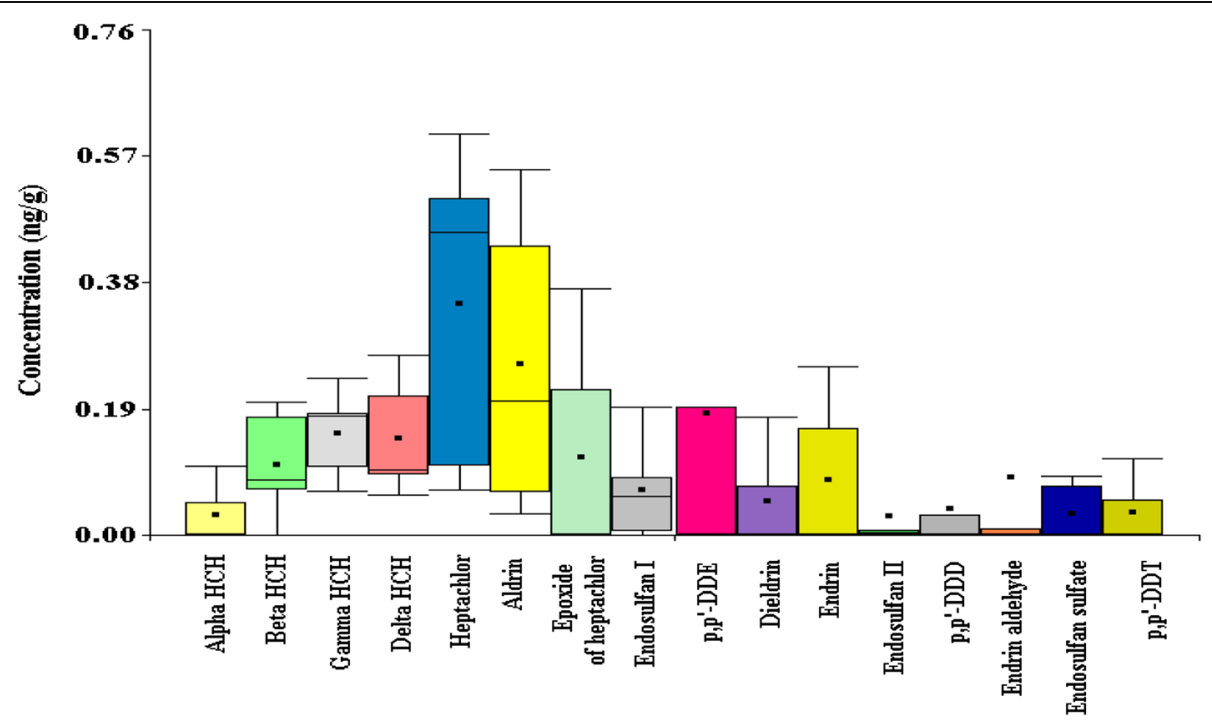

Fig. 1 Average levels of organochlorine pesticides in Xoconostle peel from Hidalgo, Mexico 
convention and the presence of DDE and DDD is the result of degradation of DDT, which is persistent in the environment.

Organochlorine pesticides enter biota by the respiratory and digestive systems, and through the skin. The chemical structure determines the dominant mode of entry. For example, DDT is absorbed minimally through the skin, while aldrin and endrin are absorbed relatively quickly by this method. The speed of adsorption after digestion is increased for substances dissolved in animal fat or vegetable wax (Keikotlhaile et al., 2010).

The presence of organochlorine pesticides in agricultural crops and processed foods also indicates the need for improving residue control at production, tighter regulation of pesticide spraying, and also tighter regulation in the sale of pesticides, as well as for education of farmers and the implementation of integrate pest management methods. Nevertheless, monitoring programs are increasingly important and essential to ensure minimal pesticide residue levels in food (Narayan et al. 2012; Wang et al., 2013; Okoffo et al., 2016).

The presence of organochlorine pesticides in food as fruits, vegetable leaf and seed is a major topic due to the human health risks such as reproductive impairment and suppression of the immune system which can have long-term consequences for population viability.

\section{Conclusion}

The occurrence of organochlorine pesticides in Xoconostle is not considered amongst the maximum permissible residue levels considered by the Codex Alimentarius, so there is a need for regulation of this food source. The use of Xoconostle peel for fermentation and fodder is acceptable and poses little risk to the health of consumers according to comparison with other vegetables. The differences of occurrence of organochlorine pesticides in the study area were probably due to differences in environmental conditions such as topography, wind direction and vegetation that protect the plots.

Organochlorine pesticides are undoubtedly candidates for continuing monitoring studies due to their persistence in the environment. Their presence in Xoconostle peel and fruit should be monitored as typically consumption is of the raw fruit without lengthy periods of storage. There is great potential for the use of traditional vegetables for human consumption and it is highly desirable to understand and limit the presence of contaminants in these food sources.

In addition, farmers in the study area should be educated with respect, the right amounts to use and the frequency of application of these pesticides in Xoconostle plantation. This will help prevent the use of unapproved or banned pesticides as well as reduce the amounts of pesticide residues in the environment.

\section{Acknowledgements}

This research was supported by Autonomous Metropolitan University by financial support in the development of the research. The authors also wish to thank Dr. Richard Gibson for his comments for this manuscript.

\section{Authors' contributions}

JJP and RO wrote the manuscript, thay have research interests in organic pollutants in food. MLR and DR carried out much of practical work in the laboratory. JO and DM collected samples in the field. All authors read and approved the final manuscript.

\section{Competing interests}

All involved authors declare that they have no personal economic or private institutional interest related to this research. All data reported was generated by research in the laboratories of the researchers involved.

\section{Author details}

'Departamento de Producción Agrícola y Animal, Laboratorio de Análisis Instrumental, Universidad Autónoma Metropolitana, Unidad Xochimilco, Calzada del Hueso No 1100, Colonia Villa Quietud, Delegación Coyoacán C.P. 04960, D.F., México. ²Departamento de Producción Agrícola y Animal, Laboratorio de Fitopatología, Universidad Autónoma Metropolitana, Unidad Xochimilco, Calzada del Hueso No 1100, Colonia Villa Quietud, Delegación Coyoacán C.P. 04960, D.F., México.

Received: 29 April 2016 Accepted: 9 November 2016

Published online: 01 December 2016

\section{References}

Chen CH, Qian Y, Chen Q, Tao CH, Li CH, Li Y. Evaluation of pesticide residues in fruits and vegetables from Xiamen, China. Food Control. 2011;22:1114-20.

Codex Alimentarius. Residuos de plaguicidas en Alimentos y Piensos. http://www.fao.org/fao-whocodexalimentarius/standards/pestres/pesticides/es/. Accessed 14 Nov 2015.

EPA (Environmental Protection Agency US). Method 3540c Soxhlet extraction. 1996. www.epa.gov/hw-sw846/sw-846-test-method-3540c-soxhlet-extraction. Accessed 25 Aug 2015.

EPA (Environmental Protection Agency US). Method 3620C Florisil cleanup. 2014. https://www.epa.gov/sites/production/files/2015-12/documents/3620c.pdf. Accessed 25 Aug 2015

EPA (Environmental Protection Agency US). Method 8081B Organochlorine pesticides by Gas Chromatography. 2007. https://www.epa.gov/sites/ production/files/2015-12/documents/8081b.pdf. Accessed 25 Aug 2015.

FAO (Food and Agriculture Organization of the United Nations). The State of Food Insecurity in the World. Meeting the 2015 international hunger targets: taking stock of uneven progress. Rome: FAO. 2015. p. 56.

Fenik J, Tankiewicz M, Biziuk M. Properties and determination of pesticides in fruits and vegetables. Trends Anal Chem. 2011:30(6):814-26.

Gutiérrez JA, Pinzón MI, Londoño A, Blanch D, Rojas AM. "Residuos de plaguicidas organoclorados, organofosforados y análisis fisicoquímico en piña (Ananas comosus L.)". Agro Sur. 2010:38(3):199-211.

Guzmán MSH, Morales MAL, Mondragón JC, Herrera HG, Guevara LF, Reynoso CR. "Physicochemical, Nutritional and Functional Characterization of Fruits Xoconostle (Opuntia matudae) Pears from Central-México Region". J Food Sci. 2010;75(6):C485-92

Instituto Nacional de Ecología. "Nopal tunero Opuntia spp. Cultivo alternativo para las zonas áridas y semiáridas de México" Comisión Nacional de las Zonas Áridas. 2003. http://www.inecc.gob.mx/descargas/publicaciones/70.pdf. Accessed 25 Aug 2015.

Keikotlhaile BM, Spanoghe P, Steurbaut W. Effects of food processing on pesticide residues in fruits and vegetables: A meta-analysis approach. Food Chem Tox. 2010;48:1-6.

Latif $Y$, Sherazi STH, Bhanger MI. Assessment of pesticide residues in commonly used vegetables in Hyderabad, Pakistan. Ecotoxicol Environ Saf. 2011;74: 2299-2303.

Morales P, Ramírez-Moreno E, Cortes SMM, Carvalho AM, Ferreira ICFR. Nutritional and antioxidant properties of pulp and seeds of two xoconostle cultivars (Opuntia joconostle F.A.C. Weber ex Diguet and Opuntia matudae Scheinvar) of high consumption in Mexico. Food Res Int. 2012;46:279-285. 
Narayan-Sinha S, Vardhana-Rao MV, Vasudev K. Distribution of pesticides in different commonly used vegetables from Hyderabad, India. Food Res Int. 2012;45:161-9

NORMA Oficial Mexicana NOM-007-RECNAT-1997 Que establece los procedimientos, criterios y especificaciones para realizar el aprovechamiento, transporte y almacenamiento de ramas, hojas o pencas, flores, frutos y semillas. DOF 30 de mayo de 1997. www.ordenjuridico.gob.mx/Publicaciones/CDs2006/ CDAmbiente/pdf/NOM3.pdf. Accessed 1 Oct 2015.

Okoffo ED, Fosu-Mensah BY, Gordon CH. Persistent organochlorine pesticide residues in cocoa beans from Ghana, a concern for public health. Int J Food Contamination. 2016:3:5. doi:10.1186/s40550-016-0028-4

Osorio-Esquivel O, Ortiz-Moreno A, Álvarez V, Dorantes-Álvarez L, Giusti M. Phenolics, betacyanins and antioxidant activity in Opuntia joconostle fruits. Food Res Int. 2011:44:2160-68.

Pérez MA, Navarro H, Miranda E. "Residuos de plaguicidas en hortalizas: problemática y riesgos en México" Rev Int de Contaminación Ambiental 29 (Número especial sobre plaquicidas). 2013. p. 45-64.

Saenz C, Berger H, Corrales J, Galletti L, García V, Higuera I, Mondragón C, Rodríguez A, Sepúlveda E, Varnero MT. Utilización agroindustrial del nopal. Boletín de Servicios Agrícolas de la FAO. Roma, Italia. 2006. 84 p.

Wang S, Wang Z, Zhang Y, Wang J, Guo R. Pesticide residues in market foods in Shaanxi Province of China in 2010. Food Chem. 2013:138:2016-25.

\section{Submit your manuscript to a SpringerOpen ${ }^{\circ}$ journal and benefit from:}

- Convenient online submission

- Rigorous peer review

- Immediate publication on acceptance

- Open access: articles freely available online

- High visibility within the field

- Retaining the copyright to your article

Submit your next manuscript at $\gg$ springeropen.com 